\title{
Antifertility Effect of Centella asiatica (L) Urban and Plucea indica (L) Urban on The Number of Follicles, Antioxidant Activity and Hormonal Profile of White Rat's Ovaries
}

\author{
Bayyinatul Muchtaromah ${ }^{1 a}$, Mukholifah $^{1}$, Ihda Sayidatun Nasiroh ${ }^{1}$, Mujahidin Ahmad ${ }^{1}$, and \\ Romaidi $^{2 b}$ \\ ${ }^{1}$ Animal Physiology Laboratory, Department of Biology, Faculty of Science and Technology, \\ State Islamic University of Malang, Indonesia \\ ${ }^{2}$ Biochemistry Laboratory, Department of Biology, Faculty of Science and Technology, State \\ Islamic University of Malang, Indonesia

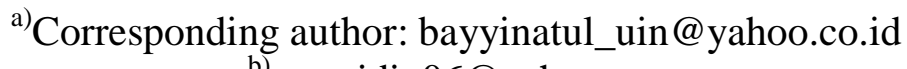 \\ b) romaidi_06@yaho.com
}

\begin{abstract}
Antifertility agents with safety and effectiveness in terms of minimum side effects have always been a subject of debate. Many studies have been conducted on plants to observe the antifertility effect, but majority of them were toxic. Centella asiatica and Plucea indica leaves have been traditionally used as medicine for its properties to promote antifertility effect. The objective of the present study was to investigate the combination effects of $C$. asiatica and $P$. indica leaf extract to the number of follicles, antioxidant activity, and hormonal profile of female rats. Thirty two fertile female rats $(2$ months), were divided into six groups and treated with different formula of the combination of $C$. asiatica and $P$. indica leaf extract: group 1 (T1) with $25+25 \mathrm{mg} / \mathrm{kg}$ bw, group 2 (T2) with $50+50 \mathrm{mg} / \mathrm{kg}$ bw, group 3 (T3) with $75+75 \mathrm{mg} / \mathrm{kg}$ bw, group 4 (T4) with $125+125$ $\mathrm{mg} / \mathrm{kg}$ bw, (T5) group 5 with $200+200 \mathrm{mg} / \mathrm{kg}$ bw, and control group (T0) treated with only 0,5\% $\mathrm{Na}$ CMC. They were also fed for 42 days. The rat's blood serum was taken for hormonal analysis, as well they were sacrificed and the ovarium were removed for histological and antioxidant analysis. The results revealed that $C$. asiatica and $P$. indica leaf extract influences to the number of follicles, antioxidant activity and hormonal profile of the rats. Group 4 (T4) showed the highest antifertility effect on the ovulation number (corpus lutium), total of ovarian follicles, and level of estrogen, respectively. Group 5 (T5) showed the highes level of superoxide dismutase (SOD) and the lowest level of Malondialdehide (MDA). It is concluded that $C$. asiatica and $P$. indica exhibited antifertility effects on reproductive system of the female rats.
\end{abstract}

Keywords: Centella asiatica, Plucea indica, number of follicles, antioxidant activity and hormonal profile

\section{INTRODUCTION}

Centella asiatica and Plucea indica leaves have been widely and traditionally used as medicine for its properties to promote antifertility effect. $C$. asiatica contain some of active compound such as triterpenoid saponins (asiaticoside and madecassoside), genin, essential oils, flavonoids, phytosterols, sugars and other active ingredients such as tannins, amino acids, fatty acids, alkaloids and salts mineral. $C$. asiatica contains approximately $1-8 \%$ triterpenoid saponins. 
Triterpenoid saponins serves to enhance the activation of macrophages. Triterpenoid saponin is able to stimulate the production of collagen I, a protein boosters wound healing process (Gupta and Kumar, 2006). The active compounds was also found in $P$. indica such as tannins, alkaloids and flavonoids, which were reported to reduce the number of spermatogenic cells and testosterone.

Fitriyah (2009) reported that the administration of $C$. asiatica extract for 30 days with a dose of 25,50 and $75 \mathrm{mg} / \mathrm{kg}$ bw increased the number of follicles, while a dose of 100 and 125 $\mathrm{mg} / \mathrm{kg}$ bw decreased the number of follicles in the ovaries of mice. While Muchtaromah (2011) reported that follicles number decreased in a dose of $125,200,275 \mathrm{mg} / \mathrm{kg}$ bw when compared to the control. Tannin in $P$. indica can cause sperm clumping, alkaloids suppress the secretion of testosterone so disturbed spermatogenesis process while flavonoids inhibit the enzyme aromatase, enzyme that catalyzes the conversion of androgens to estrogen, as well flavonoids will increase the hormone testosterone. The objective of the present study was to investigate the combination effects of $C$. asiatica and $P$. indica leaf extract to the number of follicles, antioxidant activity, and hormonal profile of female rats.

\section{METHOD}

The fresh leaves of C. asiatica and P. indica were obtained from Materia Medica, Batu Malang. The procedure for the extraction of $\mathrm{C}$. gigantea leaves referred to the procedure previously described by Muchtaromah et al. (2016) on Centella asiatica leaves. This study employed an experimental design using a completely randomized design (CRD).Thirty two fertile female rats (2 months), were divided into six groups and treated with different formula of the combination of C. asiatica and P. indica leaf extract: group 1 (T1) with $25+25 \mathrm{mg} / \mathrm{kg}$ bw, group 2 (T2) with $50+50$ $\mathrm{mg} / \mathrm{kg}$ bw, group 3 (T3) with $75+75 \mathrm{mg} / \mathrm{kg}$ bw, group 4 (T4) with $125+125 \mathrm{mg} / \mathrm{kg}$ bw, group 5 (T5) with $200+200 \mathrm{mg} / \mathrm{kg}$ bw, and control group (C) treated with only 0,5\% Na CMC. They were also fed for 42 days. The rat's blood serum was taken for hormonal analysis, as well they were sacrificed and the ovarium were removed for histological and antioxidant analysis. The data were statistically analyzed using one way ANOVA and different between each treatment was analysed by DMRT analysis.

\section{RESULT}

The results revealed that $C$. asiatica and $P$. indica leaf extract influences to the number of follicles, antioxidant activity and hormonal profile of the rats. Group 4 (T4) showed the highest antifertility effect on the ovulation number (corpus lutium), total of ovarian follicles, and level of estrogen, respectively. Group 5 (T5) showed the highes level of superoxide dismutase (SOD) and the lowest level of Malondialdehide (MDA). 


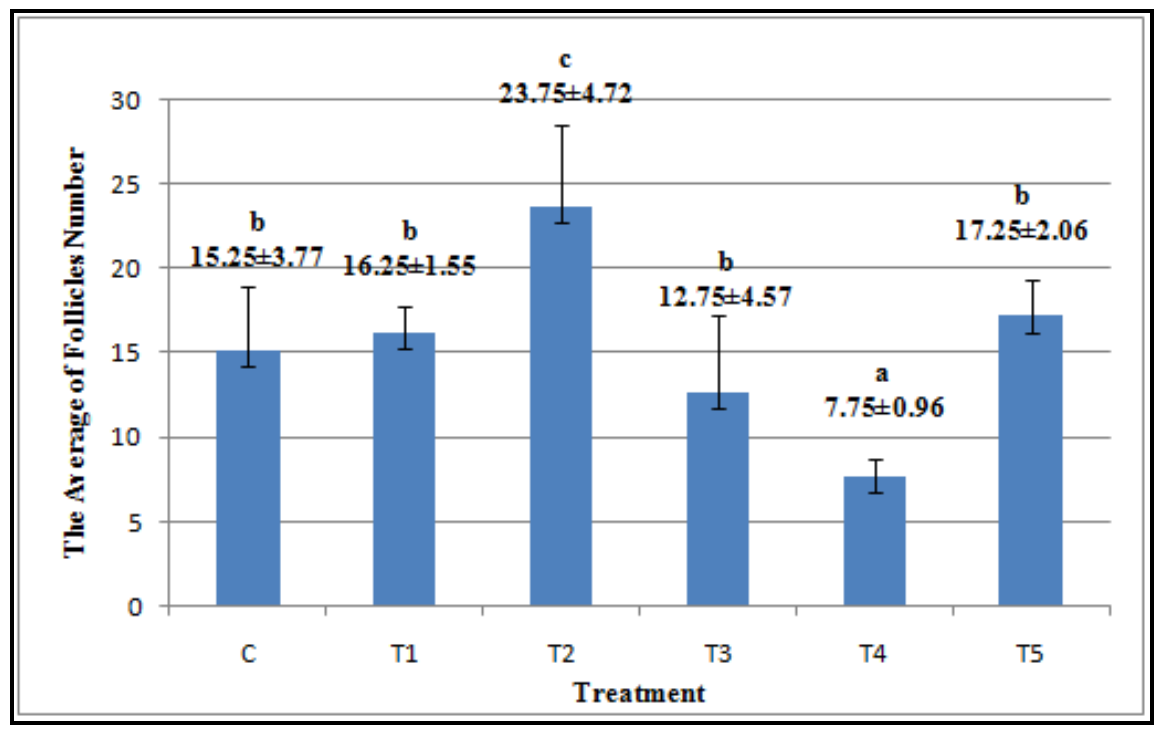

(a)

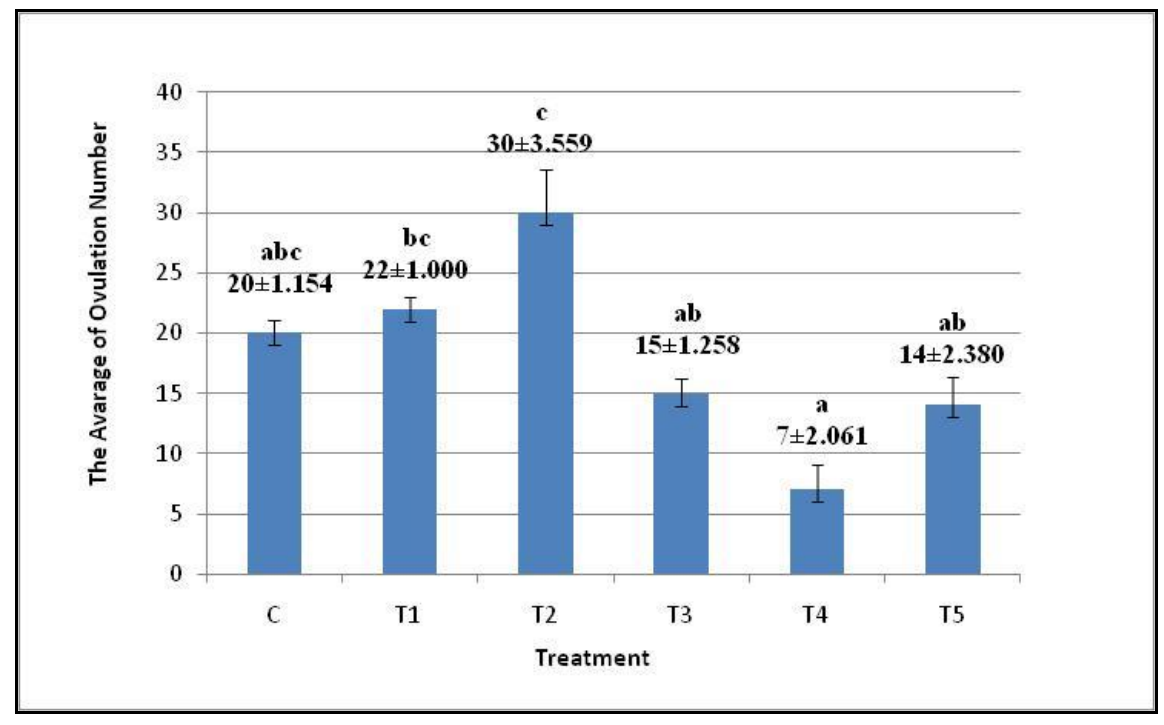

(b)

Fig. 1(a), (b) The effect on combination leaf extract of C. asiatica and P. indica on the follicle and ovulation number

Fig. 1(a,b) showed that enhancement (control, T1 and T2 group) and decreasing (T3, T4,T5 group) of total follicle and ovulation were affected by kind of doses. It might be due to the contribution of triterpenoid in C. asiatica and $P$. indica which function as estrogen like. In high concentration will give negative feed back to hypothalamic-pituitary-ovarium axis and thus inhibit the release of Luteizing Hormon (LH) dan Follicle Stimulating Hormon (FSH). The decreasing of LH and FSH will also decrease follicle and ovulation number. C. asiatica has an additional bioactive substances, flavonoid that contain high phenols such as quercetin, kaempferol, catechin, rutin, apigenin and narigin, as well as volatile oils such as caryophyllene, farnesol and various trace elements (Hashim, 2011). Agrawal, et al (2005) mentions that isoflavone can be used as a substitute for estrogen. Isoflavones have two forms of structures that form estradiol those are genistein and diadzein. Genistein and diadzein have a working mechanism estrogen-like that work 
on 17- $\beta$ estradiol receptor. This is proven by the activity of SERM (selective estrogen receptor modulator) in fitoestrogen (Oseni, 2008).

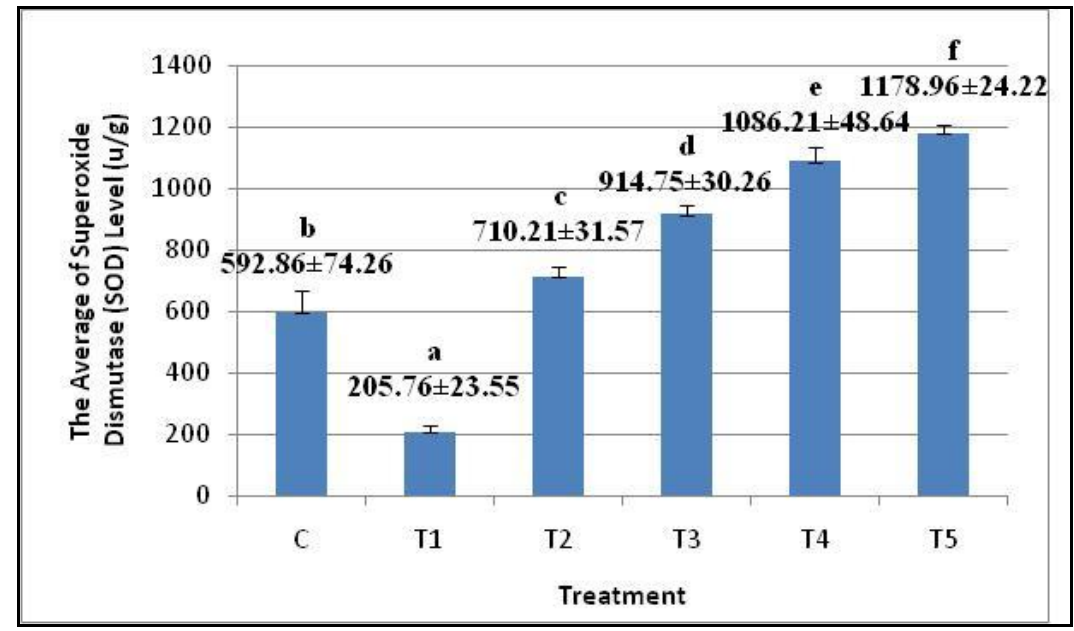

(a)

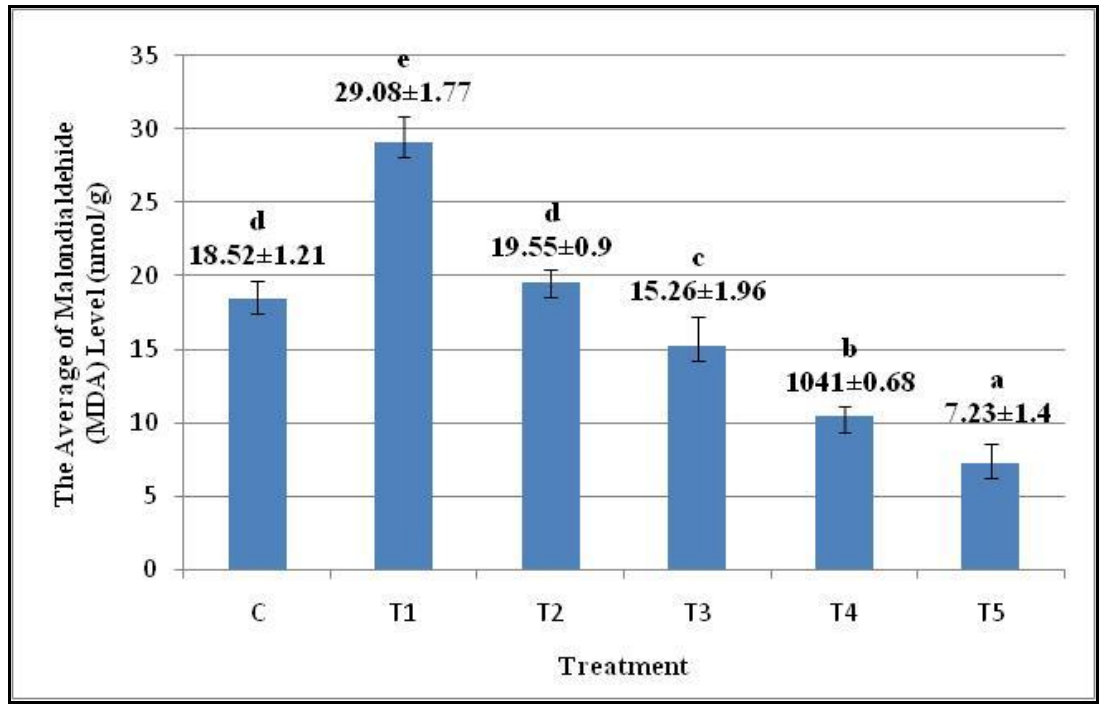

(b)

Fig. 2. The effect on combination leaf extract of C. asiatica and $P$. indica on the antioxidant activity. (a) Superoxide dismutase (b) Malondialdehide

Fig 2a. shows that antioxidant activity (SOD level) increase in all group (treatments) unless the control group. Active compound in $C$. asiatica and $P$. indica such as triterpenoid, flavonoid and tannin is though to be responsible in modulating SOD enzyme endogen as well it may also protect from free radical in the body (Kefer dan Agarwal, 2009). Triterpenoid, for example, could dilute in lipid and thus it can be grouped in mechanism of secondary antioxidant which function in reducing auto-oxidation reaction by changing lipid to the stable one (Brinkhaus, et al. 2000). Another compound, flavonoid, generally could neutralize free radical by capacitating antioxidant mechanism and stimulate gen which is responsible antioxidant enzyme synthesis. While tannin has antioxidant activity and inhibit enzyme such as reverse ${ }^{e e}$ transcriptase dan DNA topoisomerase. Fig 2b. shows the decreasing of MDA level with the increasing of doses. MDA is toxic compound, which is the final product of the stop carbon ring of lipid acid in lipid peroxidation process. The 
low level of MDA indicate the status of high concentration of antioxidant in the body, as well as in opposite manner.

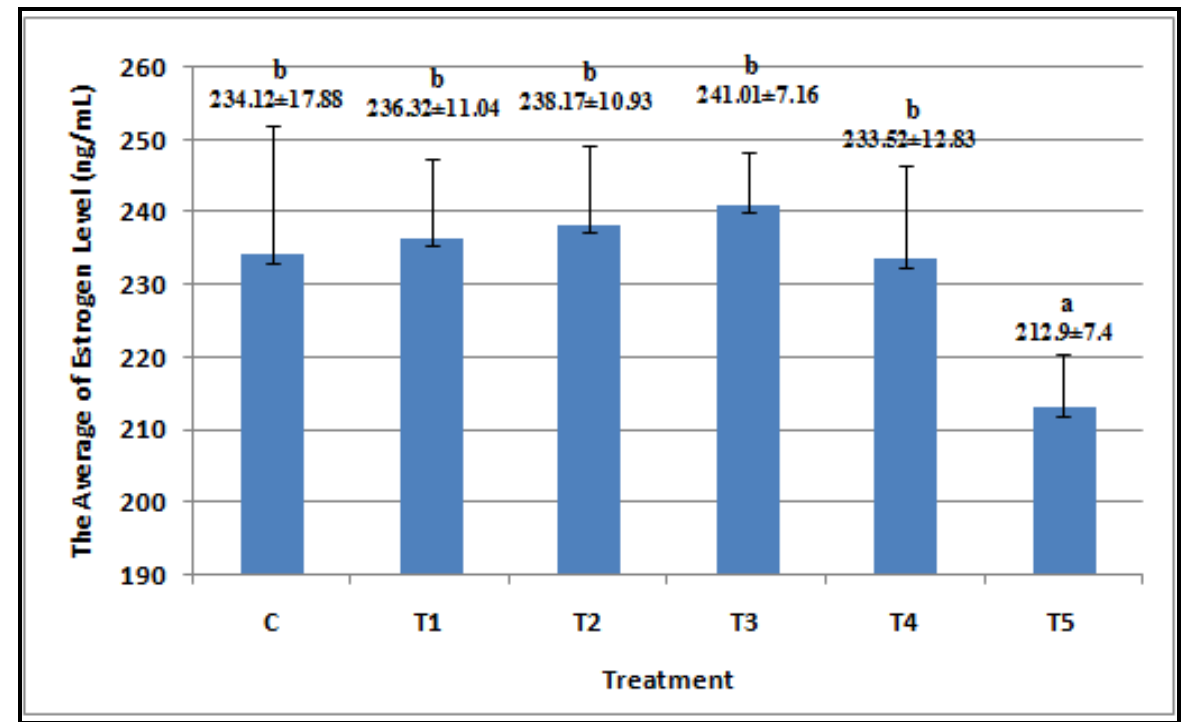

Fig. 3. The effect on combination leaf extract of C. asiatica and P. indica on the Estrogen profile

Based on Fig 3. High dose group (T5) was significantly different from the control and all treatments. It might be due to stereoid contents such diosgenin atau genin in triterpenoid saponin. Andria (2012) reported that genin could be altered as progesteron by chemical process and final product testosteron and estrogen. The high concentration of estrogen inhibits hipothalamushipofisis anterior by negative feed back, and thus FSH and LH are not released to anterior hipofisis. This condition disturbs the development of follicle ovarium cell, and finally the estrogen level decreases as well the ovulation is also stopped.

In conclussion, $C$. asiatica and $P$. indica exhibited antifertility effects on reproductive system of the female rats and promised contraceptive medicine in the future.

\section{References}

Gupta, Y.K. dan M.H.V. Kumar. 2003. Effect of Centella asiatica on Cognition and Oxidative Stress in an Intracerebroventricular Sterptozotocin Model of Alzheimer's Disease in Rats, Clin Exp. Pharmacol. Physiol, 30 : 336-342.

Fitriyah. 2009. Pengaruh Pemberian Ekstrak Daun Pegagan (Centella asiantica) terhadap Perkembangan Folikel Ovarium Mencit (Mus musculus).Skripsi Tidak Diterbitkan. UIN Maliki Malang.

Muchtaromah, B. Pengaruh Ekstrak Pegagan (Centella asiatica (L) Urban) Dosis Tinggi terhadap Profil Folikel Ovarium Mencit (Mus musculus) Betina. Berkala Penelitian Hayati (Journal of Biological Researches). Edisi Khusus No. 4D . Juni Tahun 2011..

Muchtaromah, B., Ahmad, M., Suyono, S., Romaidi, R., Bahri, S. \& Kumalasari, H. P. Dosage and administration length of Centella asiatica (L.) Urban decrease the level of SOD and MDA and improve brain histological condition of rats. Jurnal Teknologi 78, 57-61.2016

Hashim, P. 2011. Mini Review Centella asiatica in Food and Beverage Applications and Its Potential Antioxidant and Neuroprotective effect. International Food Research Journal, 18(4): 1215-1222. Hedrich HJ. 2006. Taxonomy and stock and strains. J Lab Rat 71-92

Agarwal, A., Gupta, S., and Sharma,R.K. Role of Oxidative Stress in Female Reproduction.Reprod. Biol. Endocrinol. 3: 38. 2005 
Oseni, T, Patel, R, Pyle, J and Jordan,CV. Selective Estrogen Receptor Modulators and Phytoestrogens. Planta Med. Oct; 74(13): 1656-1665. 2008. doi: 10.1055/s-00281088304.

Brinkhaus, B., M. Lindner, D. Schuppan and EG. Hahn. Chemical,pharmacological and clinical profile of the east asian medicinal plant Centella asiatica, Phytomedicine. 7(5): 427-448. 2000.

Kefer, JC., and A. S.E. Agarwal Role of antioxidants in the treatment of male infertility. Inernational Journal of Urology 16: 449 - 57. 2009.

Andria, Y. 2012. Pengaruh Pemberian Ekstrak Daun Pegagan (Centella asiatica (L) Urban) terhadap Kadar Hormon Estradiol dan Kadar Hormon Progesteron Tikus Putih (Rattus norvegicus) Betina.Tesis. Universitas Andalas Padang. 2012. 